\title{
Rammya Mathew: Why are doctors so unhappy?
}

\author{
Rammya Mathew GP
}

London

I've always been curious as to why so few doctors recommend a career in medicine. Not only do they not recommend it but some actively discourage it. ${ }^{1}$ This will no doubt come as a surprise to those outside medicine who perceive it as a highly sought-after and prestigious professional career. So, what is it that makes us deter our friends and family from following in our footsteps?

Researching this question led me to a 2001 editorial published in The BMJ by Richard Smith, editor at the time, discussing why doctors were "so unhappy." ${ }^{2}$ This shows us that professional dissatisfaction is not a new phenomenon. There are many age old frustrations, such as trying to manage an unmanageable workload and having to work within the confines of a system that doesn't always help you to help the patient. But we go into medicine knowing that it's not going to be an easy ride-so there must be more to it than this.

It's often assumed that working in a field that's service oriented brings an automatic sense of meaning and purpose. ${ }^{3}$ Yet I look back on my days as a junior doctor and think about the number of hours I spent couriering forms around the hospital. Now, as a GP, I spend a substantial proportion of my day going through the post that comes to our practice. Our jobs aren't defined by daily acts of heroism, so, despite being in a job that's centred on service, we still need to work on finding meaning in our work and staying connected to our sense of purpose.

Doing a contraceptive pill check can be viewed as a basic set of tasks, including checking a woman's weight and blood pressure and exploring her other risk factors for venous thromboembolism. But what if we viewed it as an interaction that could reduce unwanted pregnancies and the reproductive injustices faced by women? ${ }^{4}$

In medicine we frequently refer to jobs that need doing, patient lists that need completing, and bed numbers that need reviewing. When this is the prevailing narrative, it's no wonder that we've become so detached from any sense of mission or purpose. If we are to reignite our passion for the job, and if we want to make it a career that we can talk about with pride, then we must consciously put people back at the heart of everything we do. Not just for the sake of patients but for the sake of our own happiness too.

Competing interests: I co-lead Islington GP Federation's Quality Improvement Team.

Provenance and peer review: Commissioned; not externally peer reviewed.

Moberly T. Only a 10 th of doctors would recommend a career in medicine. BMJ 2015;351:h517010.1136/bmj.h5170.

2 Smith R. Why are doctors so unhappy? There are probably many causes, some of them deep. BMJ 2001;322:1073-4. 10.1136/bmj.322.7294.1073 11337419

3 Coleman J. To find meaning in your work, change how you think about it. Harv Bus Rev 2017. https://hbr.org/2017/12/to-find-meaning-in-your-work-change-how-you-think-aboutit

4 Tsai A, Moniz MH, Davis MM, Chang T. Meaning and purpose: refocusing on the why in medical education. NEJM Catal 2017. 10.1056/CAT.17.0437. https://catalyst.nejm.org/ meaning-and-purpose-medical-education/. (Subscription needed.)

Published by the BMJ Publishing Group Limited. For permission to use (where not already granted under a licence) please go to http://group.bmj.com/group/rights-licensing/ permissions 